\title{
THE MORPHOPHONOLOGY OF THE AKAN REDUPLICATED VERB-FORM
}

\author{
Charles Osofu Marto \\ University of Kwame Nkrumah University of Science and Technology \\ Ghana
}

\begin{abstract}
This paper discusses the interaction between constituent formation and alteration of sounds (i.e., morphophonology) in Akan reduplicated verbforms. Specifically, we strive to look into two issues; the morphology of reduplicated verb stems and how the morphological manifestation(s) affect certain target sounds. With its morphology, we observe that reduplication of the Akan verb-stem is generally total and, through the Morphological Doubling Theory (Inkelas 2005; Inkelas and Zoll 2005), reduplication of Akan verb-stems is viewed as the double (or multiple) occurrence of a morphological constituent meeting a particular morpho-semantic description. That is to say, while there could be differences in structure between the reduplicant and the base, they are subject to a common phonology that determines a resulting shape of an output. With morphophonology, we observe that three issues are relevant in the discussion of the phonology of the reduplicated verbs in Akan. These are the application of vowel harmony, vowel shift in terms of height, and the realization of tonal semblance. Through thorough discussions, the paper finally explains that reduplication of verbstems in Akan is morphophonologically driven.
\end{abstract}

\section{Keywords}

Akan, morphophonology, reduplication, vowel harmony and height, tone

\section{INTRODUCTION}

Reduplication, which has generally been described as the systematic recurrence of a unit within a word for semantic or grammatical purposes (e.g. Marantz (1982), Rubino (2005)), has enjoyed much attention in the literature with regard to various lexical categories and how it pertains in different languages (see e.g. Tuvan (Raimy 2000; Harrison and Raimy 2004), Sanskrit (Steriade 1988) and, Squamish and Chichewa (Downing 2008)). On Akan in particular, Dolphyne (1988), Winkler and Obeng (2002), among others, have looked at reduplication in some respect in various categories. In this paper, we particularly look at the interaction between constituent formation and 
alteration of sounds in Akan reduplicated verb-forms, i.e. morphophonology of reduplicated verb-forms in Akan.

As noted by Moravcsik (1978) and in diverse languages, particularly in some Kashaya verbs (Oswalt 1961), which is also the case in Akan, reduplication of verbs is used to express repetitive or iterative and distributive ideas. In Akan, it also arguably indicates intensification in some instances of the verb and other categories. Thus the verb $b \boldsymbol{o}^{\prime}$ 'to hit', when reduplicated as $b \dot{o} b o$, indicates that the act of hitting is done more than once and not on one point or place as expressed in (1). Thus, in (1) we have a sense of not just a 'hit', but more than one of it and more rigorous as well, which actually underscore its translation as 'beat up'.
1. Àtàá bò bó-j̀
Kòfí
PN hit.hit-PAST Kofi
'Ataa beat up Kofi.'

As (1) indicates, therefore, it is commonplace to realize a different sense of a verb-stem in its reduplicated form in Akan.

The rest of the paper is sectionalized as follows: In section 2, we focus on what pertains in categories of reduplicated Akan verb-stems. In this direction, we strive to have a detailed morphological account of the reduplicated verbstems within the Morphological Doubling Theory (e.g. Inkelas and Zoll (2005)). In section 3, we identify and underscore two forms of verb-stems, i.e. reduplicated monosyllabic and polysyllabic verb stems, as a necessity in the quest of exploring how their individual morphological manifestations, some of which are explained in section 2, affect the realization of some target sounds (thus, phonology) in the reduplicated form. Finally, affirming the fact that reduplication of the Akan verb-stem is morphophonologically-driven, section 4 concludes the paper.

\section{MORPHOLOGY OF AKAN REDUPLICATED VERB-STEMS}

It is generally noted that reduplication is a morphological process (see, for example, Singh (2003), Rubino (2005), Skinner (2008)) and, typologically, two types of reduplication have been distinguished, as in Rubino (2005). These are full and partial reduplication; where full is complete repetition of the stem and partial is repetition of only a part of the stem. We observe that reduplication in the Akan verb-stem is generally full (or total) in terms of segments and it is also left-directed; i.e. what is being repeated (hereafter, the reduplicant) comes before the stem (the base).

Looking at the issue of direction first, for ease of explaining succeeding points, we note that the left-direction of reduplication of Akan verb-stems is established on the fact that the phonetic form of the stem is maintained and 
made evident in the succeeding constituent, the base. This observation is further established by an aspect of the phonology of the language, specifically vowel harmony as a regressive rule (see section 3.1). Thus, in Akan, the structure of reduplicant-base, specifically described as 'CONSTITUENT $1_{\text {reduplicant-CONSTITUENT } 2 \text { base' }}$ ' structuring, is the case. This is exhibited in the reduplicated forms in (2) below, compared to the basic forms.

\begin{tabular}{|c|c|c|c|c|}
\hline \multirow[t]{2}{*}{2.} & \multicolumn{2}{|c|}{ Basic form (BF) } & \multirow{2}{*}{$\frac{\text { Reduplication (RF) }}{\text { bò- } b j}$} & \multirow{2}{*}{$\frac{\text { Re-reduplication }}{\text { bòbj-bòbj }}$} \\
\hline & bó & 'to hit' & & \\
\hline & tùà & 'to pay' & tùà-tùà & tùàtùà-tùàtùà \\
\hline & hy $\varepsilon^{\prime}$ & 'to wear' & hyè-hyغ่ & hyèhy $\varepsilon^{\prime}-h y e ̀ h y \varepsilon^{\prime}$ \\
\hline & sá & 'to dance' & sè-sà & sèsà-sèsà \\
\hline & hyìrà & 'to bless' & hyìrà-hyìrà & hyìràhyìrà-hyiràhyìrà \\
\hline & kùm & 'to kill' & kùǹ-kùmi & kùǹkùm-kùṅkùm \\
\hline
\end{tabular}

On the totality of reduplication of Akan verb-stems, as could also be witnessed from (2), it is evident that the whole verb-stem is reduplicated and, in this case, the base and the reduplicant are numerically identical. ${ }^{1}$ Total reduplication seems to be well-established in the language in the sense that, as could also be seen in the last column of (2), reduplicated forms could further be reduplicated and there is total reduplication of the reduplicated verb-stem in this case. In other words, the totality of reduplication of Akan verb-stems is even evident in reduplicated reduplications. From this observation, reduplication of verb-stems in Akan could be described as double (or multiple) occurrence of a morphological constituent, as the Morphological Doubling Theory (Inkelas 2005; Inkelas and Zoll 2005, etc.) suggests. That is, a morphological construction calls for two independent input stems whose morpho-syntactic features are in agreement; i.e. the two stems meet a particular morpho-semantic description. Observing the Morphological Doubling Theory (MDT) further, we note that each input stem (noted as a daughter node) is subject to a co-phonology that determines its shape. However, the outputs of the two stem co-phonologies are combined and subjected to a third co-phonology at this combined stage (noted as the mother node) that produces a surface form. This and other postulations of MDT is structurally captured in (3), a recast from Inkelas (2005).

Observing MDT further, the diagram in (3) shows that there are often differences between the phonology of the base and that of the reduplicant.

\footnotetext{
${ }^{1}$ There are a few cases in which total reduplication is not the case, e.g. hóró 'to wash' and $\mathrm{d} \square$ ré 'to be fat/riped' are respectively reduplicated as hòhòrò and $\mathrm{d} \square \mathrm{d} \square$ rè. However, this partial reduplication could be explained as phonologically conditioned; simply put, a final syllable with $/ \mathrm{r} /$ onset is often done away with. Thus, even in unduplicated form, they could also be pronounced as hó and $\mathrm{d} \square$.
} 
Instances of this are seen in most reduplicated verb-stems in Akan; e.g. dì-dj (from the basic form, $d j$ ' to weed'). Here, we observe differences in vowel(s) in the base and the reduplicant, indicating differences in phonology. Despite these variations, they share a common morpho-semantic description. Further, as MDT suggests, the reduplicant and the base are also subject to a common phonology that determines a resulting shape (or final morphological structure) of an output that feeds into the morpho-semantic significance. In other words, together, as the data in (4) show, the base and the reduplicant bring out a common morpho-semantic form in the output of a reduplicated verb. In Akan, the base (and for that matter reduplication) is indeed instrumental in the phonology of the reduplicant and the realization of the reduplicated verbstem.

3.

\section{Reduplicated Form (RF)}

(Meaning $=$ aspect of reduplicant + aspect of base;

Phonology $=$ reduplicant phonology + base phonology)

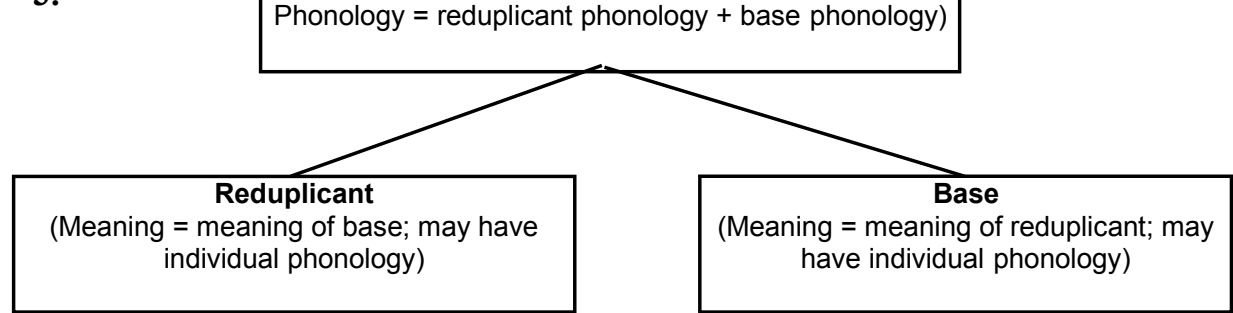

An interesting case in the reduplication of Akan verb-stems that is capable of adducing objection to MDT is where the reduplicated verb is put in the negative. We observe that the negative affix $/ \mathrm{n}-/$ reflects only in the reduplicant (or immediately seen as having been attached to the reduplicant); e.g. tùàtùà becomes ì-tùá-tùà, not *n்-tùá-ì-tùà. ${ }^{2}$ In other words, the negative morpheme, which is with the stem in the basic form (i.e. $\dot{n}$-tùa 'don't pay'), does not show up in the base (in the reduplicated form) but, rather, in the reduplicant; hence $\dot{\boldsymbol{n}}$-tùa $\dot{a}_{\text {reduplicant }}$-tùà. This realization in other data is exemplified in (4).

One could therefore argue that a common morphology (of the morpho-semantic description), which MDT preaches, has not been met. In this case, the Akan data will not be consistent with MDT although a common semantic description could be contended for as having been met between the base and the reduplicant.

Comprehensively redeeming MDT, however, it could be explained that a common morpho-semantic description has been attained between the base and the reduplicant on the grounds that the negative morpheme $/ \mathrm{n}-/$ is only a morphophonemic constituent which the whole reduplicated form inflects for.

\footnotetext{
${ }^{2}$ Generally, verbal affixes, including aspects, are not reduplicated with the stem.
} 


\begin{tabular}{|c|c|c|c|c|}
\hline 4. & BF & & Negated BF & Negated RF \\
\hline & $\mathrm{bo}$ & 'to hit' & ṁbó (mimó) & mimòbs' \\
\hline & dwìrà & 'to cover' & ǹ-dwìrá ('̀̀ nwìrá) & rinwìrádwìrà ${ }^{3}$ \\
\hline & hys' & 'to wear' & ǹ $h y \varepsilon^{\prime}$ & ṅhyèhy $\varepsilon^{\prime}$ \\
\hline & sá & 'to dance' & ǹsá & risèsá \\
\hline & hyìrà & 'to bless' & ǹhyìrá & rihyìráhyìrà \\
\hline & kùm’ & 'to kill’ & ǹkúḿ & ìkùǹ kúḿ \\
\hline
\end{tabular}

In other words, the reduplicant does not come into the reduplicated form as negative-inflected. Rather, the inflection is done after reduplication (in the affirmative). This argument is supported by the fact that it is the base which could inflect for the negative marker in isolation, as noted earlier and exemplified in (4). Indeed, as inflectional material to the stem, the negative morpheme could only be inflected to the stem when the stem-reduplication is complete.

Considering the morphology of reduplicated verb-stems in Akan, we have our working definition of reduplication (of verb-stems) in the language as a morphological process that relates a base (here, a verb-stem) to a derived form (i.e. a reduplicated verb-stem) that may be analyzed as being constructed from the base form via the doubling of phonemic material which is necessarily identical in whole to the base. While our definition is analysis-specific, it is our view that it is not entirely different from some other definitions in the literature (see, for example, Marantz (1982), Rubino (2005)). We continue with the phonology and, indeed, the morphophonology of the reduplicated verb-stems in the following section.

\section{3. PHONOLOGY OF AKAN REDUPLICATED VERB-STEMS}

We have noted that reduplication of the Akan verb-stem is generally used to encode the iterative and or distributive nature of the verb, among others. We have also observed reduplication as a morphological process and appreciably looked at how it is realized in Akan verb-stems. In terms of phonology, we also observe that reduplication of verb-stems in Akan also invokes application of some phonological rules, resulting in some alterations in the output. These phonological rule applications follow from the

\footnotetext{
${ }^{3}$ Observe that the stem-initial consonant /dw/ becomes /nw/ in the negated form. This is due to a phonological process Marfo (2009) calls voiced-to-nasal assimilation. With application of voice-to-nasal assimilation, a stem-initial voiced stop becomes a nasal after a nasal prefix with the same specification of the nasal prefix, thus /dw/ becoming $/ \mathrm{nw} /$ after $/ \mathrm{n} /$. This also applies in compounds, in which case an initial voiced stop in a succeeding compound member becomes a nasal with the specification of the final nasal in its preceding compound member.
} 
assumption that reduplication, as a normal word formation process, precedes all phonological rule applications in the derivation of a reduplicated form (e.g. Marantz (1982)). In other words, as morphologically derived structure, reduplication could affect the phonology of a language (resulting in morphologically-conditioned phonology (Downing 2008)) and indeed, more often than not, the reduplicated form is expected to be subjected to some phonological rules. Hence, as Raimy (2000: 2) notes, reduplication is discussed in this section as resulting from properties from both phonology and morphology and, particularly, resulting from the interaction between these two components of grammar.

In the exploration of the structure of reduplicated Akan verb-stems, three morphologically-conditioned phonological alterations become relevant. These alterations have to do with the principle vowel harmony, the issue of vowelshift with regard to height (which is described as ablaut in this paper) and tonal ramifications (specifically, tonal semblance). Through a thorough individual and/or connected discussion of these phenomena and related issues, we intend to show in this section that reduplication of verb-stems in Akan is morphophonologically driven.

In order to understand the phonological processes (effecting the segmental alterations) in reduplicated Akan verb-stems better, we distinguish between two basic verb-stems in Akan: monosyllabic and polysyllabic forms. Examples of the two are shown in (5).

\begin{tabular}{|c|c|c|c|c|c|c|}
\hline \multirow[t]{2}{*}{5.} & \multicolumn{3}{|c|}{ Monosyllabic } & \multicolumn{3}{|c|}{ Polysyllabic } \\
\hline & $\mathrm{BF}$ & & $\mathrm{RF}$ & $\mathrm{BF}$ & & RF \\
\hline & bj́ & 'to hit' & bòbj & tùà & 'to pay' & tùàtùà \\
\hline & hyย́ & 'to wear' & hyèhy $\dot{\varepsilon}$ & hyìrà & 'to bless' & hyìràhyìrà \\
\hline & sá & 'to dance' & sèsà & gyìnà & 'to stop' & gyìnàgyìnà \\
\hline & fé & 'to vomit' & féfé & pòtว̀ & 'to mash' & pòtjpòt j \\
\hline & kó & 'to fight' & kókó & fèkyèrè & 'to scrutinize' & fèkyèrèfèkyèrè \\
\hline
\end{tabular}

The monosyllabic-disyllabic distinction is necessary because, as will be discussed in the following sub-sections, some of the identified phonological processes manifest differently in the two types of verb-stems. Before that, even in the basic (unduplicated) form, one could also realize that tone is different in pattern between the monosyllabic and polysyllabic stems. That is to say, while monosyllabic stems are H-toned, polysyllabic stems are Ltoned. $^{4}$

\footnotetext{
${ }^{4}$ Let us note that Akan is a two-tone language; i.e., it employs high tone $(\mathrm{H})$ and low tone (L) in the grammar. $\mathrm{H}$ is indicated with an acute (e.g., dá 'day') and $\mathrm{L}$ is indicated with a grave (e.g., dà 'never'). There is also a case of downstepped $\mathrm{H}$ after another H (e.g., àdá!ká 'a box'), but this is seen as only a variety of the $\mathrm{H}$ tone.
} 


\subsection{Vowel harmony and vowel-shift in reduplicated verb-stems}

The principle of vowel harmony (VH) in Akan has been discussed in the literature (e.g., Berry (1957), Dolphyne (1988), O'keefe (2003), Marfo and Yankson (2008)). Some aspects of it that are relevant to this paper are that VH in Akan is a regressive rule, and that it has to do with the advancement of the tongue root (i.e., ATR) in the articulation of vowels (Berry 1957; Clements 1981; Hulst and Weijer 1995; Marfo and Yankson 2008); i.e., the positions of the tongue root during the production of each of the ten phonetic vowels in Akan. Thus, in Akan, a vowel is either produced with an advanced tongue root (i.e. $[+\mathrm{ATR}])$ or with a retracted tongue root $([-\mathrm{ATR}])$. The $[+\mathrm{ATR}]$ vowels are $[\mathrm{i}, \mathrm{e}, \mathrm{o}, \mathrm{u}, \mathrm{a}]$ and the $[-\mathrm{ATR}]$ are $[\mathrm{I}, \varepsilon, \supset, \mathrm{v}, \mathrm{a}]$. Following this distinction, the $\mathrm{VH}$ principle generally requires that all vowels occurring in a (prosodic) word must come from one and only one of the sets. That is, vowels occurring in a word must share a common ATR specification. We note in passing, however, that there are a few words within which $\mathrm{VH}$ is violated, resulting in a two-span harmony. ${ }^{5}$

$\mathrm{VH}$ is set off in the Akan reduplicated verb-stem and it is satisfied accordingly; i.e. reduplication as a morphological phenomenon has provided a platform for the application of VH. Specifically, as noted earlier, reduplication is left-directed in Akan and, since $\mathrm{VH}$ is a regressive rule, it is enabled to take place from the base to the reduplicant in the 'CONSTITUENT $1_{\text {reduplicant }}$-CONSTITUENT $2_{\text {base }}$ ' structure. Considering MDT (as briefly discussed above), one could also say that this is not surprising; i.e. the reduplicant is only a doubling of the base (but the reduplicant and the base may be of different phonology, as MDT also suggests and will be exemplified soon). ${ }^{6}$ Accordingly, as in (6), one could witness the ATR specification of the base and, indeed, total vowel identity between the corresponding syllables in the reduplicant-base morphology ('CONSTITUENT $1_{\text {reduplicant" }}$ CONSTITUENT $2_{\text {base }}$ ').

\begin{tabular}{|c|c|c|c|c|}
\hline \multirow[t]{2}{*}{ a } & \multicolumn{4}{|l|}{ Monosyllabic } \\
\hline & $\mathrm{BF}$ & & RF & \\
\hline & {$\left[\mathrm{f}_{\mathrm{I}}\right]$} & 'to vomit' & fèfè & {$\left[f_{I} f_{I}\right]$} \\
\hline & {$\left[\mathrm{k}_{U}\right]$} & 'to fight' & kòkò & {$[\mathrm{k} u \mathrm{k} v]$} \\
\hline
\end{tabular}

\footnotetext{
${ }_{6}^{5}$ See Clements (1981) and Marfo (2009) for some details on the two-span harmony.

${ }^{6}$ Alternatively, even with a suggestion that the reduplicant is not due to morphological doubling, which a theory like the Correspondence Theory (e.g. McCarthy and Prince 1995) would advocate for, and that vowels in the reduplicant are immediately unspecified for ATR, the reduplicant must ultimately share the ATR specification of the base considering the fact that $\mathrm{VH}$ in Akan is regressive in application and the position that reduplication in Akan verb-stems is left-directed, as noted in the main text.
} 


$\begin{array}{lllll}\text { gyé } & {\left[\mathrm{d} \mathrm{F}_{\mathrm{I}}\right]} & \text { 'to take' } & \text { gyègyè } & {\left[\mathrm{d} \mathrm{z}_{\mathrm{I}} \mathrm{d} \mathrm{I}_{\mathrm{I}}\right]} \\ \text { nú } & {[\mathrm{nu}]} & \text { 'to tickle' } & \text { nùnù } & {[\mathrm{nunu}]} \\ \text { sí } & {[\mathrm{si}]} & \text { 'to build' } & \text { sìsi } & {[\mathrm{sisi}]}\end{array}$

So, vowel harmony is straightforward in reduplicated verb-stems and does not separate the reduplicant from the base. In this case, one could say that the reduplicant and the base even share a common phonology.

\begin{tabular}{|c|c|c|c|c|c|}
\hline \multirow[t]{2}{*}{ b. } & \multicolumn{5}{|c|}{ Polysyllabic } \\
\hline & \multicolumn{3}{|c|}{$\mathrm{BF}$} & \multicolumn{2}{|l|}{ RF } \\
\hline & sìnè & [sone] & 'to sieve' & sònèsìnè & [s $\supset$ nes $\supset$ e] \\
\hline & pòtò & [poto] & 'to mash' & pòtว̀pòtว̀ & [putsputo] \\
\hline & dèǹkyì & [dentçi] & 'to capsize' & dèǹkyìdèǹkyì & [dentcidenții] \\
\hline & kyèrદ’ & {$[\operatorname{tg} \mathrm{I} r \varepsilon]$} & 'to show & kyèrżkyèrè & [tgI $\left.r_{\varepsilon t g} I r_{\varepsilon}\right]$ \\
\hline & pòrì & [pori] & 'to stumble & pòrìpòrì & [poripori] \\
\hline
\end{tabular}

Looking at all data given so far, however, the reader must have observed that there are some verb-stems that exhibit some vocalic differences in the reduplicant-base morphology. It is important to note here that this is particularly the case with the monosyllabic verb-stems and, indeed, this is particularly the reason why a clear distinction between stems (i.e. the monosyllabic-disyllabic distinction that has been noted earlier) is necessary and had to be observed in the discussion of the phonology of reduplicated verb-stems. As the data in (7) exemplify, while vowel harmony is still straightforward in both reduplicated monosyllabic (7a) and disyllabic (7b) verb-stems, total vowel identity is constrained; it is attained in reduplicated polysyllabic verb-stems but not in reduplicated monosyllabic verb-stems. Hence those marked with asterisk in (7a) are ill-formed in the language.

\begin{tabular}{|c|c|c|c|c|c|c|}
\hline \multirow[t]{2}{*}{ a. } & \multicolumn{6}{|c|}{ Monosyllabic } \\
\hline & \multicolumn{3}{|c|}{$\mathrm{BF}$} & \multicolumn{3}{|l|}{ RF } \\
\hline & sá & [sa] & 'to scoop' & sèsà & [sı sa] & ${ }^{*}$ [sasa] \\
\hline & twá & [t64a] & 'to cut' & twitwa & [t64itça] & ${ }^{*}\left[{ }_{6} 4 \mathrm{atc}_{6} \mathrm{Ya}\right]$ \\
\hline & fáḿ & [fam] & 'to paste' & femfam & {$\left[f_{\mathrm{I}} \mathrm{mfam}\right]$} & ${ }^{*}[$ famfam $]$ \\
\hline & bó & [bo] & 'to hit' & bòbj & [bubo] & ${ }^{*}[\mathrm{~b} \supset \mathrm{b} \supset]$ \\
\hline & kyé & {$[\mathrm{ky} \varepsilon]$} & 'to donate' & kyèkyغ̇ & [t6r t6e $]$ & *[tcetce $]$ \\
\hline
\end{tabular}

\begin{tabular}{|c|c|c|c|c|}
\hline \multirow[t]{2}{*}{ b. } & \multicolumn{4}{|l|}{ Polysyllabic } \\
\hline & $\mathrm{BF}$ & & RF & \\
\hline & [sone] & 'to sieve' & sònèsìnè & [sonesone] \\
\hline & [cira] & 'to mash' & hyìràhyìrà & [hyirahyira] \\
\hline & [dentci] & 'to capsize' & dèǹkyì̀dèǹkyì & [dentçidentçi] \\
\hline
\end{tabular}




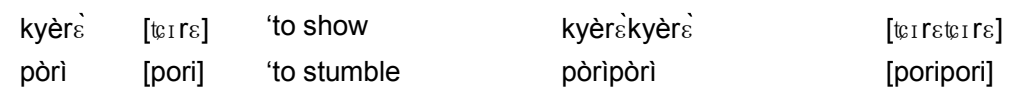

Considering the cases in (7a), the change of vowel in the reduplicant (and, ultimately, in the reduplication) has to do with the phonological sonority of the vowel in the base and this ultimately marks the difference in phonology between the base and the reduplicant.

Phonological sonority has variously been discussed as having to do with syllable structure. It has been dubbed universal in the sense that, across languages, it plays a very important role in determining what sequences of sounds are permissible (in a syllable) and this is based on the fact that speech sounds are related on a scale of loudness or intensity (see, for example, Selkirk (1984), and Ladefoged (1993)). Ladefoged (1993), in particular, defines sonority of a sound as its loudness as compared to that of other sounds with the same length, stress, and pitch. In the case of vowels, it is generally assumed that the lower a vowel, the more sonorous (or louder) it is (Selkirk 1984). Thus, as the diagram in (8) reflects, [a] is the most sonorous among the vowels in Akan and the set $[\mathrm{i}, \mathrm{u}, \mathrm{I}, \mathrm{v}]$ is the least sonorous. ${ }^{7}$

Akan vowel inventory (Dolphyne (1988))
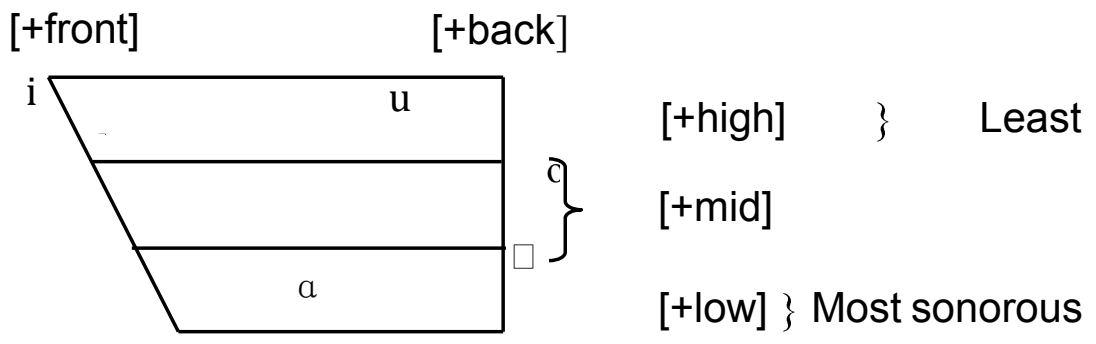

With reference to (7a), we argue on the basis of the sonority hierarchy, ATR harmony, and labialization, that a vowel in the base of a monosyllabic verb-stem cannot be copied in the morphological double (i.e. in the reduplicant) as long as this vowel is not among the least sonorous vowel set (i.e. $[i, u, I, v]$ ) and, for that matter, a high vowel. This is because, as economy of speech would predict, least sonorous sounds (here, high vowels) are

\footnotetext{
${ }^{7}$ Following Selkirk (1984) for example, the sonority hierarchy or scale is given as vowels $>>$ liquids $>$ nasals $>>$ fricatives $>$ affricates $>>$ stops, where ' $x>>y$ ' indicates ' $x$ is more sonorous than $y$ '. It is also important to note that, among each category, there is a ranking of sonority as well. Thus, as we have done in text with the ten phonetic vowels in Akan, low vowel are the most sonorous, followed by mid vowels and high vowels come in that order.
} 
preferred. In other words, unlike the data given in (7a), where the vowel in the stem is least sonorous, the reduplicant and the base are identical, as shown in (9) below. This explains that ablaut, a vowel change (specifically, a vowel shift to high) due to the desire for a least sonorous vowel, is applicable here.

Extending the argument we have made in the reduplicated monosyllabic verb-stems to reduplicated polysyllabic stems, we conjecture that perhaps the reason why reduplicated polysyllabic stems usually have reduplicant-base vowel identity in corresponding syllables is that the vowels are not of the same higher sonority level (i.e. /a/). This could be observed in the data given so far on the reduplicated polysyllabic stems. We note however that there are a few polysyllabic verb-stems within which all vowels are highly sonorous (i.e. all are /a/), as exemplified in (10), and these could immediately be described as constituting exceptional case.

\begin{tabular}{|c|c|c|c|c|c|}
\hline \multirow[t]{2}{*}{9} & \multicolumn{5}{|c|}{ Monosyllabic } \\
\hline & \multicolumn{3}{|c|}{$\mathrm{BF}$} & \multicolumn{2}{|l|}{ RF } \\
\hline & sí & [si] & ‘to build’ & sìsì & [sisi] \\
\hline & twé & {$\left[{ }_{6} \mathrm{H}_{\mathrm{I}}\right]$} & ‘to pull’ & twètwè & [ $\left.{ }_{6} \mathrm{LI}_{\mathrm{t}} \mathrm{t}_{\mathrm{I}}\right]$ \\
\hline & fóḿ & [fom] & 'to scramble for' & fòmfòm & [fomfom] \\
\hline & bú & [bu] & 'to break' & bùbù & [bubu] \\
\hline & kyé & [kye] & 'to catch' & kyèkyè & [6 I I t 6 I ] \\
\hline
\end{tabular}

\begin{tabular}{|c|c|c|c|c|c|}
\hline \multirow[t]{2}{*}{10.} & \multicolumn{5}{|c|}{ All-sonorous polysyllabic stems } \\
\hline & BF & & & RF & \\
\hline & pàtà & [pata] & 'to pacify' & pàtàpàtà & [patapata] \\
\hline & kàsà & [kasa] & 'to talk' & kàsàkàsà & [kasakasa] \\
\hline & kàtà & [kata] & 'to cover' & kàtàkàtà & [katakata] \\
\hline & hàtà & [hata] & 'to dry' & hàtàhàtà & [hatahata] \\
\hline & bàtà & [bata] & 'to adjoin' & bàtàbàtà & [batabata] \\
\hline & wàdà & [wada] & 'to stay put & wàdàwàdà & [wadawada] \\
\hline & wàsà & [wasa] & 'to smear & wàsàwàsà & [wasawasa] \\
\hline & dwàtà & [dzYata] & 'to divide ...' & dwàtàdwàtà & [dz $\mathrm{d}_{z} \mathrm{atad}_{z}$ Yata] \\
\hline & kwàhà & [kwaha] & 'to douche' & kwàhàkwàhà & [kwahakwaha] \\
\hline & màǹtàm & [mantam] & 'to tie' & màǹtàmmàǹtàm & [mantammantam] \\
\hline
\end{tabular}

There could, however, be a phonological explanation for this all-sonorous polysyllabic stems in Akan. On a critical look, one realizes that the onset of the succeeding syllable (let us call it a transitional unit here) is always among the least sonorous consonant sets; i.e. it is always a fricative, an affricate or a stop in each one of them. The argument then for their occurrence in the language, which is very much informed by the principle of economy of speech, is that a sequence of the highly sonorous segment, /a/, is essentially and desirably broken by a least sonorous sound. By universal sonority-based 


\section{VOLUME 6}

phonotactics principle, therefore, the string is well-formed. In other words, a string of the highly sonorous vowel /a/ has been thwarted with intervening least sonorous consonants.

\subsection{Tone in reduplicated verb-stems}

In the immediately preceding section, we pointed out that monosyllabic stems are distinguished from polysyllabic ones by tone pattern; i.e., in isolation, monosyllabic verb-stems are usually said with $\mathrm{H}$ tone and polysyllabic ones are said with $\mathrm{L}$ tone. This is particularly shown in (5), repeated as (11).

\begin{tabular}{|c|c|c|c|c|c|c|}
\hline \multirow[t]{2}{*}{11.} & \multicolumn{3}{|c|}{ Monosyllabic } & \multicolumn{3}{|c|}{ Polysyllabic } \\
\hline & $\mathrm{BF}$ & & RF & $\mathrm{BF}$ & & RF \\
\hline & $b j$ & 'to hit' & bòbj & tùà & 'to pay' & tùàtùà \\
\hline & hyย́ & 'to wear' & hyèhyغ̇ & hyìrà & 'to bless' & hyìràhyìrà \\
\hline & sá & 'to dance' & sèsà & gyìnà & 'to stop' & gyìnègyìnà \\
\hline & fé & 'to vomit' & féfé & pòtj & 'to mash' & pòtว̀pòtj \\
\hline & kó & 'to fight' & kókó & fèkyèrè & 'to scrutinize' & fèkyèrèfèkyèrè \\
\hline
\end{tabular}

In the reduplicated forms (i.e. in a morphologically-conditioned environment), however, we observe that both monosyllabic verb-stems and polysyllabic ones are said on $\mathrm{L}$ tone. The question then is: Does the reduplication have anything to do with its tonology? In other words, does the lengthening of a base (which has indeed resulted from reduplication) impact tonal representation? Considering the reconciliation here between the monosyllabic stems and the polysyllabic ones in the use of the $\mathrm{L}$ tone in the reduplicated forms (see (11)), we assume a general sensitivity of tone to reduplication. That is to say, the representation of tone in reduplicated verbstems is generally morphological length-controlled and that tone interacts with morphological length in reduplication. This analysis could be wellsupported even in the basic form (BF) by the fact that, while a verb-stem with one-syllable morpheme is readily pitched for $\mathrm{H}$ tone, those with more than one (including the morphologically doubled, reduplicated forms) are said with the default $\mathrm{L}$ tone.

Winkler and Obeng (2002) seem to suggest an alternative analysis to the L tone realization in reduplicated forms (not particularly on verbal ones). Comparing reduplication in Limonese Creole and Akan, they note that the tonal prosodic features found in their data include key lowering, downdrifting, and downstepping (downtrends); ${ }^{8}$ suggesting that these processes have been triggered by reduplication. Indeed, considering the fact that downtrends normally involve interaction of contrastive tones (see, for example, Hombert

\footnotetext{
${ }^{8} \mathrm{We}$ refer to all of them as downtrends, following Connell (2001).
} 
(1974), Connell (2001)), which they partially note, such a suggestion could hardly be conclusive. We suggest, however, that a radical position based on Winkler and Obeng's observation could do the trick of accounting for the realization of the $\mathrm{L}$ tone in reduplicated verb-stems. This radical shift stems from a further assumption here that downtrends could/should be looked at as phonological phenomena, rather than a phonetic one. In this direction, assuming downdrift as the case in the reduplicated verb-stems, it could be represented in the phonology by all $\mathrm{L}$ tones on a stretch of utterance and, in this particular case, the reduplicated verb-stem. That is to say, in the Akan reduplicated verb-stem, downdrift should not only be described as "the progressive lowering of a high tone after a low tone" (Hombert 1974: 171), but as due to the phonological manifestation of downdrift.

\section{CONCLUSION}

We have looked at reduplication of the Akan verb-stem and noted that, among others, reduplication is generally used to encode the iterative and or distributive nature of the verb. We have also appreciably looked at how reduplication, as a morphological process, is realized in Akan verb-stems. The realization has been explained through the Morphological Doubling Theory (MDT), which establishes that a morphological construction calls for two independent inputs of different co-phonology (that determines their individual shapes), whose morpho-syntactic features are in agreement, and that outputs share a third co-phonology that produces a surface form.

Phonologically and, specifically, in terms of how morphology affects phonology, three phonological alterations have been noted and have been described as having to do with the principle of $\mathrm{VH}$, vowel-shift with regard to height and tone realization. We have explained that since reduplication is leftdirected in Akan verb-stems, thus realizing the structure 'CONSTITUENT $1_{\text {reduplicant }}$-CONSTITUENT $2_{\text {base }}$,' $\mathrm{VH}$, which is a regressive rule in Akan, is set to apply in it; i.e. from the base to the reduplicant and this indeed has been the case. Through vowel shift (from low to high), we have also explained the need for a least sonorous vowel in a reduplicant whose base contains only the most sonorous vowel /a/. This analysis has particularly been seen with the monosyllabic base and has been extended to the polysyllabic base. Last, but not the least, tone realization has been observed as being generally sensitive to reduplication, resulting in phonological downdrift.

\section{REFERENCES}

Berry J. 1957. Vowel Harmony in Twi, Bulletin of the School of Oriental and African Studies, University of London, Vol. 19, No. 1, Cambridge: Cambridge University Press on behalf of School of Oriental and African Studies. 
Berry, Jack. 1957. Vowel harmony in Twi. Bulletin of the School of Oriental and Africa Studies 19:124-130.

Clements, George N. 1981. Akan vowel harmony: A nonlinear analysis. Harvard Studies in Phonology 2:108-173.

Connell, Bruce. 2001. Downdrift, downstep, and declination, Proceedings of Typology of African Prosodic Systems Workshop, Bielefeld University, Germany, May 18-20, 2001.

Dolphyne, Florence Abena. 1988. The Akan (Twi-Fante) Language: Its Sound Systems and Tonal Structure, Accra: Ghana Universities Press.

Downing, Laura J. 2008. Co-phonologies and morphological exponence in OT, Paper presented at the 3rd Exponence Network meeting and Workshop on Theoretical Morphology 4, University of Leipzig (Großbothen), 20-21 June 2008.

Harrison, K. D. and Eric Raimy. 2004. Reduplication in Tuvan: Exponence, readjustment and phonology, Proceedings of WAFL 1: Workshop in Altaic Formal Linguistics by A. Csirmaz, Y. Lee and M. A. Walter. (xxx) MITWPL 46, Cambridge, MA.

Hombert, J-M. 1974. Universals of downdrift: their phonetic basis and significance for a theory of tone, Studies in African Linguistics, Suppl. 5, 169-183.

Hulst, Harry van der, and Jeroen van de Weijer. 1995. Vowel harmonies, The Handbook of Phonological Theory 495-534, John Goldsmith (ed.), Oxford: Blackwell.

Inkelas, Sharon and Cheryl Zoll. 2005. Reduplication: Doubling in Morphology, Cambridge Studies in Linguistics 106, Cambridge: Cambridge University Press.

Inkelas, Sharon. 2005. Morphological doubling theory: Evidence for morphological doubling in reduplication, Bernhard Hurch (ed.) Studies in Reduplication 65-88, Berlin, New York: Mouton de Gruyter.

Inkelas, Sharon. 2005. Morphological doubling theory: Evidence for morphological doubling in reduplication, Bernhard Hurch (ed.) Studies in Reduplication 65-88, Berlin/New York: Mouton de Gruyter.

Ladefoged, Peter. 1993. A Course in Phonetics (third edition), Fort Worth: Harcourt Brace Jovanovich College Publishers.

Marantz, Alec. 1982. Re reduplication, Linguistic Inquiry 13: 483-545.

Marfo, Charles. 2009. Aspects of Akan Grammar and the Phonology-Syntax Interface. Saarbrücken: Lambert Academic Publishing.

Marfo, Charles and Solace Yankson. 2008. The structure of the 'CCV' syllable of Akan, Concentric: Studies in Linguistics 34.2: 85-100.

McCarthy, John and Alan Prince. 1995. Faithfulness and Reduplicative Identity, Papers in Optimality Theory 249-384, Beckman, L. Walsh Dickey and S. Urbanczyk (eds.), GLSA, UMass Amherst.

Moravcsik, Edith. 1978. Reduplicative constructions, Universals of Human Language, Vol. 3: 297-334, Joseph Greenberg (ed.), Stanford: Stanford University Press.

O'keefe, Michael. 2003. Akan Vowel Harmony, An unpublished B.A. thesis, Swarthmore College.

Oswalt, Robert L. 1961. A Kashaya grammar: Southwestern Pomo, PhD dissertation, University of California, Berkeley.

Raimy, Eric. 2000. Remarks on backcopying, Linguistic Inquiry 31:541-552. 
Raimy, Eric. 2000. The Phonology and Morphology of Reduplication, Studies in Generative Grammar 52, Berlin/New York: Mouton de Gruyter.

Rubino, Sharon. 2005. Reduplication: Form, function and distribution, Bernhard Hurch (ed.) Studies in Reduplication 11-29, Berlin, New York: Mouton de Gruyter.

Selkirk, Elizabeth. 1984. On the major class features and syllable theory, Language sound structure 107-136, M. Aronoff and R.T. Oehrle (eds.), Cambridge, MA: MIT Press.

Singh, Rajendra. 2003. Reduplication in Modern Hindi and the Theory of Reduplication, the Yearbook of South Asian Languages and Linguistic 155-171, Rajendra Singh (ed.), Berlin/New York: Mouton de Gruyter.

Skinner, Tobin R. 2008. Morphological Optionality in Reduplication: A Lowering Account, Proceedings of the 26th West Coast Conference on Formal Linguistics 420-428, Charles B. Chang and Hannah J. Haynie (eds.). Somerville, MA: Cascadilla Proceedings Project.

Steriade, Donca. 1988. Reduplication and syllable transfer in Sanskrit and elsewhere, Phonology 5: 73-155.

Winkler, Grace E. and S. Gyasi Obeng. 2002. A Comparison of Reduplication in Limonese Creole and Akan, Twice as meaningful: Morphological Reduplication in Pidgins and Creoles, Silvia Kouwenberg (ed.), Battlebridge Press. 